\title{
Shoot position, cutting types and auxin treatments influence rooting response on Tecoma stans
}

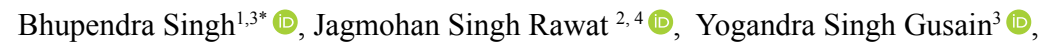 \\ Vinod Prasad Khanduri ${ }^{3}$ (D), Manoj Kumar Riyal ${ }^{3}$ (1), Prabhat Kumar $^{5}$ (1) \\ ${ }^{1}$ H.N.B. Garhwal University, Department of Forestry, Srinagar Garhwal, Uttarakhand, India. \\ ${ }^{2}$ H.N.B. Garhwal University, Department of Horticulture, Srinagar Garhwal, Uttarakhand, India. \\ ${ }^{3}$ V.C.S.G. Uttarakhand University of Horticulture and Forestry, Department of Forestry, \\ College of Forestry, Ranichauri, Tehri Garhwal, Uttarakhand, India. \\ ${ }^{4}$ Department of Horticulture, Govt. Degree College, Rudraprayag, Uttarakhand, India. \\ ${ }^{5}$ National Coordinator, National Agriculture Higher Education Project (NAHEP), Krishi Anusandhan Bhawan - II, Pusa Campus, New Delhi, India
}

\begin{abstract}
This study investiges the rooting ability and the growth performance of lower and upper shoot positions and type of the cuttings, i.e. soft and hard wood and leafy and non leafy, of Tecoma stans (L.) Kunth. The cuttings were collected from 4-year old plants growing in the Chauras Campus of H.N.B. Garhwal University Srinagar Garhwal, Uttarakhand, India. The rooting ability of cuttings was studied under the treatments of indole-3-butyric acid (IBA) and Indole 3-acidic acid (IAA) under $0.0 \%, 0.3 \%$, $0.4 \%, 0.5 \%$ concentration in both hormones. The rooting response was significantly $(p<0.05)$ better in $0.4 \%$ IBA compared to other treatments and control ( $0 \%$ IBA and IAA). The ratio of number of roots to rooted cuttings and length of root to rooted cuttings in the different treatments showed significant differences $(p<0.05)$. The rooted cuttings were further transferred, into the polythene bags and shifted to open nursery conditions. Under such conditions, the rooted cuttings treated with $0.4 \%$ and $0.5 \%$ IBA demonstrated the highest $(90 \%$ to $100 \%)$ survival capacity in the lower portion soft wood and leafy stem cuttings. Plantable plant and plant height was greater in the $0.4 \%$ IBA concentration treatment. The results of the study suggest that rooting of soft wood stem cuttings having lower position and leaves could be an effective mean of regenerating to T. stans. Furthermore, the application of $0.4 \%$ IBA concentration treatment is appropriate for rooting of juvenile leafy stem cuttings in a mist chamber. Keywords: IAA, IBA, leafless, powder medium, root growth, shoot growth.
\end{abstract}

\section{Resumo}

Posição da brotação, tipos de corte e tratamentos com auxina influenciam a resposta de enraizamento em Tecoma stans Este estudo investiga a capacidade de enraizamento e o desempenho de crescimento das posições inferiores e superiores dos ramos e do tipo de estaca, ou seja, madeira macia e dura, com folhas e sem folhas de Tecoma stans (L.) Kunth. As estacas foram coletadas de plantas com 4 anos de idade, crescendo no Campus Chauras de H.N.B. Garhwal University Srinagar Garhwal, Uttarakhand, Índia. O enraizamento das estacas foi estudado sob os tratamentos de ácido indol-3-butírico (IBA) e ácido indol 3-ácido (IAA) nas concentrações de $0,0 \%, 0,3 \%, 0,4 \%, 0,5 \%$ em ambos os hormônios. A resposta de enraizamento foi significativamente $(\mathrm{p}<0,05)$ melhor em $0,4 \%$ de AIB em comparação com os outros tratamentos e controle ( $0 \%$ de AIB e AIA). A razão número de raízes para estacas enraizadas e comprimento da raiz para estacas enraizadas nos diferentes tratamentos apresentou diferenças significativas $(p<0,05)$. As estacas enraizadas foram posteriormente transferidas para os sacos de polietileno e transferidas para condições de viveiro aberto. Sob tais condições, as estacas enraizadas tratadas com $0,4 \%$ e $0,5 \%$ de AIB demonstraram a maior ( $90 \%$ a $100 \%)$ capacidade de sobrevivência na porção inferior de madeira macia e estacas folhosas. A planta cultivável e a altura da planta foram maiores no tratamento com concentração de $0,4 \%$ de AIB. Os resultados do estudo sugerem que o enraizamento de estacas de caule de madeira macia com posição inferior e folhas pode ser um meio eficaz de regeneração de T. stans. Além disso, a aplicação do tratamento com concentração de $0,4 \%$ de AIB é apropriada para o enraizamento de estacas juvenis com folhas em câmara de neblina.

Palavras-chave: IAA, IBA, estaca desfolhada, meio em pó, crescimento radicular, crescimento de parte aérea.

*Corresponding author: butola_bs@yahoo.co.in 


\section{Introduction}

Tecoma stans (L) Juss. ex. Kunth (Bignoniaceae) is a shrub in the trumpet vine. The English name of Tecoma stans is yellow bells, yellow elder, trumpet flower and in Hindi it is known as Piliya. It bears funnel shaped, bright yellow flowers in terminal racemes or panicles. It also trained over arches or espaliered against a wall. The species is native to America and Antilles and introduced as an ornamental plant in different tropical country of the world. T. stans has shown medicinal properties against the antitumor, antioxidant, antimicrobial, hypoglycemic free radical anti-inflammatory and antidiabetic (Verma, 2016).

It is generally accepted that most perennial ornamental species are multiplied and propagated through cuttings, layering and grafting. The use of cuttings from stems, leaves, roots or terminal buds is considered as the most commonly applied technique due to its practicability and simplicity. It is well known that the success of rooting of woody stem cuttings, in the majority of ornamental plants, depends mainly on the physiological stage of the mother plant, the time of planting of the cutting (Hartmann et al., 2018) and the type of growth regulators used (Azad and Matin, 2015; Azad et al., 2016, Singh and Rawat, 2017). The prevailing environmental conditions in the nursery i.e., light, temperature and humidity play an important role in rooting and succeeding growth and development of cuttings (Hartmann et al., 2018). The rooting media in which cuttings planted influenced the root and shoot development (Ibironke, 2017). Adventitious root formation (ARF) is a crucial physiological process for propagation of many ornamental plant species. Adventitious root are generally formed during normal development and in response to stress conditions, i.e. flooding, nutrient deprivation, heavy metal stress and wounding (Steffens and Rasmussen, 2016). The ability of trees to form ARs usually declines with age (Pizarro and Diaz-Sala, 2019).

The effects of different auxins concentrations on adventitious rooting of Zanthoxylum armatum were studied previously (Singh and Rawat, 2017). Rooting in cuttings is related to endogenous plant growth regulators (Abo ElEnien and Omar, 2018). Little information is available on how the physiological age of the tissue influences the rooting in T. stans cuttings (Cerveny et al., 2006). The seeds of $T$. stans are small in size, membranous wings and long viability (Reno et al., 2007), which spread them easily by wind and the stem and roots cuttings has ability to precede roots (Biondi et al., 2008). The vegetative propagation in ornamental plant like $T$. stans is very important due to two reasons. Firstly, it is a cross-pollinated and naturally highly heterozygous plant. Its progenies produced by seeds are not true to type and loose many of their unique characteristics. Vegetative propagation helps in maintaining its genetic characteristics. Secondly, vegetatively propagated T. stans plants are precocious in bearing, i.e. they flower earlier than seed propagated plants (Personal observation of authors). This will reduce the timing to flowering which help in rehabilitating the areas more quickly. Therefore, the present study was conducted to evaluate the effects of auxin treatments in shoot position (lower and upper), leaves (leafy and non leafy) soft and hard wood cuttings on rooting response of $T$. stans.

\section{Materials and Methods}

\section{Effect of position of shoot cuttings and auxin treatments}

Tecoma stans plants were identified and tagged in the Chauras Campus, H.N.B. Garhwal University, Srinagar Garhwal, (situated at $30^{\circ} 78^{\prime} \mathrm{N}$ latitude, $78^{\circ} 30^{\prime} \mathrm{E}$ longitude and altitude of $560 \mathrm{~m}$ mean above sea level) Uttarakhand, India. The highest maximum temperature of 40 to $42{ }^{\circ} \mathrm{C}$ was recorded in the month of June in the study area. The shoots were collected to prepare the cuttings from four years old plants in the month of April 2012 when maximum air temperature of $30^{\circ} \mathrm{C}$ was recorded where mother plants were growing. Vegetatively propagated plants were planted in the campus.

Cuttings from the upper and basal position of one-yearold shoot were trimmed to $10 \mathrm{~cm}$ length with diameter between 0.5 and $1.0 \mathrm{~cm}$. All leaves were removed from cuttings. The cuttings were immersed in a solution of $0.2 \%$ Bavistin fungicide for 10 minutes and thoroughly rinsed with distilled water. Following treatments were employed to the cuttings: (1) untreated talc powder alone, (2) $0.3 \%$ IBA in talc, (3) $0.4 \%$ IBA in talc, (4) $0.5 \%$ IBA in talc, (5) $0.3 \%$ IAA in talc, (6) $0.4 \%$ IAA in talc, (7) $0.5 \%$ IAA in talc (Singh and Rawat 2017).

The lower portion of cuttings were moistened with water and dipped into the appropriate powder to a depth of $1 \mathrm{~cm}$. All treated cuttings were inserted to a depth of $3 \mathrm{~cm}$ in $100 \mathrm{~mL}$ root trainer filled with vermiculite. A total 700 cuttings ( 20 cuttings $\mathrm{x} 7$ treatments $\mathrm{x} 5$ replicates) in each position were planted. To prevent inadvertent removal of powder, a dibbler was used to insert the cuttings into the vermiculite rooting medium.

Cuttings inserted into root trainers were placed in a randomized block design in the mist chamber, having timers, weaners and electronic thermometers (times were used to control the misting applied through a weaner). Misting was applied for 1 minute and then turned off for 10 minutes. The air temperature of the mist chamber was $30 \pm 2$ ${ }^{\circ} \mathrm{C}$ and average relative humidity was maintained between $60 \%$ and $80 \%$ throughout the duration of the experiment. The vermiculite temperature was $26 \pm 2{ }^{\circ} \mathrm{C}$. After 30 days, observations on callus formation, rooting and sprouting percentage, number of sprouts per cutting, sprout length, number of roots per cutting and root length per cutting were conducted for each set. The uprooted cuttings were transferred into poly bags filled with a 1:2:1 ratio of sand, soil and farmyard manure (FYM). After 90 days of transfer, survival percent was calculated among the rooted cutting transferred into the poly bags. Similarly, plantable cutting percentage was calculated among the survival cuttings suitable for the planting in the field and their plant height $(\mathrm{cm})$ were measured with the help of meter scale. 


\section{Effect of leaves and auxin treatments}

Leafy and leafless softwood shoot cuttings (current year shoots) of T. stans were collected from the same mother plants in the month of April 2012. In the leafy cuttings top two leaves were retained and others leafs were removed, while in leafless cuttings all leaves were removed and trimmed to $10 \mathrm{~cm}$ long. The cuttings were treated with auxin as described for the earlier experiment. In this experiment, 700 cuttings were planted including seven treatments and five replicates each having twenty cuttings. Rooting and sprouting were assessed similarly as mentioned in the experiment 2.1 on shoot position.

Effect of soft wood, hard wood cuttings and auxin treatments

Lower portion of soft wood (current year shoot) and hard wood (more than one-year-old) cuttings of $T$. stans were also collected from same mother plants in the month of April 2012. The cuttings were trimmed to $10 \mathrm{~cm}$ length. All leaves were removed from cuttings. A total of 700 cuttings in each type of cuttings were planted and rooting and sprouting were assessed same as mentioned in previous experiments.

\section{Statistical analyses}

Statistical analyses were done by using SPSS software package, version 11.5 (SPSS Inc., Chicago, USA) for analysis of variance and Duncan's Multiple Range Test (DMRT) was used for comparisons of different means of different treatments (Roger, 2016).

\section{Results}

Effect of position of shoot cuttings and auxin treatments The rooting and sprouting was varied significantly $(p<0.05)$ with position of cuttings treated with different concentration of auxin and control set. The lower cuttings resulted in $95 \%$ rooting and $100 \%$ sprouting at $0.4 \%$ IBA treatment. The control cuttings from lower position showed $30 \%$ rooting and $60.0 \%$ sprouting. Number of sprouts per cutting was maximum (3.7) for lower position cuttings treated with $0.4 \%$ IBA, while sprout length per cutting was higher $(5.8 \mathrm{~cm})$ in the basal position cuttings at $0.5 \%$ IBA. The number of roots per rooted cutting was also higher (16.2) in the lower position cuttings at $0.4 \%$ IBA followed by (15.3) in $0.5 \%$ IBA concentrations. Root length per rooted cutting was greatest $(7.5 \mathrm{~cm})$ in the upper position cuttings at $0.4 \%$ IBA (Table 1 ).

Table 1. Effects of position of shoot cuttings and auxin treatment on rooting response of Tecoma stans

\begin{tabular}{|c|c|c|c|c|c|c|}
\hline Treatments & $\begin{array}{c}\text { Sprouting } \\
\%\end{array}$ & $\begin{array}{c}\text { Rooting } \\
\%\end{array}$ & $\begin{array}{l}\text { Number of sprouts/ } \\
\text { Rooted cutting }\end{array}$ & $\begin{array}{l}\text { Sprout length } \\
\text { (cm) }\end{array}$ & $\begin{array}{l}\text { Number of roots/ } \\
\text { rooted cutting }\end{array}$ & $\begin{array}{l}\text { Root length } \\
\text { (cm) }\end{array}$ \\
\hline \multicolumn{7}{|l|}{ Upper portion } \\
\hline Control & $40 \pm 3.2 \mathrm{e}$ & $20 \pm 4.5 \mathrm{e}$ & $1.0 \pm 0.28 \mathrm{c}$ & $1.0 \pm 0.86 \mathrm{e}$ & $1.3 \pm 0.65 \mathrm{c}$ & $2.7 \pm 0.76 \mathrm{e}$ \\
\hline $0.3 \%$ IBA & $55 \pm 3.5 \mathrm{de}$ & $45 \pm 6.1 \mathrm{~cd}$ & $1.6 \pm 0.52 \mathrm{~b}$ & $2.6 \pm 0.29 \mathrm{~cd}$ & $8.6 \pm 3.47 \mathrm{~b}$ & $5.7 \pm 2.49 \mathrm{bc}$ \\
\hline $0.4 \%$ IBA & $75 \pm 3.5 \mathrm{a}$ & $75 \pm 3.5 \mathrm{a}$ & $2.1 \pm 0.68 \mathrm{a}$ & $5.6 \pm 1.54 \mathrm{a}$ & $12.0 \pm 5.62 \mathrm{a}$ & $7.5 \pm 1.58 \mathrm{a}$ \\
\hline $0.5 \%$ IBA & $60 \pm 9.4 \mathrm{~cd}$ & $60 \pm 9.4 b c$ & $1.5 \pm 0.55 b$ & $4.6 \pm 2.47 \mathrm{ab}$ & $3.6 \pm 2.41 \mathrm{c}$ & $6.3 \pm 2.1 b$ \\
\hline $0.3 \%$ IAA & $55 \pm 7.1 \mathrm{de}$ & $35 \pm 7.9 \mathrm{~d}$ & $1.6 \pm 0.54 \mathrm{~b}$ & $2.0 \pm 0.26 \mathrm{de}$ & $2.5 \pm 0.27 \mathrm{c}$ & $4.5 \pm 1.05 \mathrm{~d}$ \\
\hline $0.4 \%$ IAA & $65 \pm 7.9 b c$ & $45 \pm 9.4 \mathrm{~cd}$ & $1.1 \pm 0.24 \mathrm{c}$ & $3.5 \pm 0.58 \mathrm{bc}$ & $2.6 \pm 1.41 \mathrm{c}$ & $4.3 \pm 1.9 \mathrm{~d}$ \\
\hline $0.5 \%$ IAA & $65 \pm 3.5 \mathrm{bc}$ & $60 \pm 6.1 \mathrm{ab}$ & $1.2 \pm 0.21 \mathrm{c}$ & $2.6 \pm 0.5 \mathrm{~cd}$ & $3.3 \pm 1.28 \mathrm{c}$ & $4.9 \pm 1.50 \mathrm{~cd}$ \\
\hline \multicolumn{7}{|l|}{ Lower portion } \\
\hline Control & $60 \pm 7.1 \mathrm{~cd}$ & $30 \pm 4.5 \mathrm{e}$ & $1.6 \pm 0.38 \mathrm{~cd}$ & $1.9 \pm 0.52 \mathrm{de}$ & $4.6 \pm 3.42 d$ & $3.7 \pm 0.54 \mathrm{de}$ \\
\hline $0.3 \%$ IBA & $85 \pm 5.0 \mathrm{~b}$ & $65 \pm 6.1 b c$ & $2.1 \pm 0.26 b c$ & $3.5 \pm 0.92 \mathrm{bc}$ & $12.4 \pm 4.6 \mathrm{bc}$ & $5.1 \pm 1.28 \mathrm{bc}$ \\
\hline $0.4 \%$ IBA & $100 \pm 0.0 \mathrm{a}$ & $95 \pm 3.5 \mathrm{a}$ & $3.7 \pm 0.56 \mathrm{a}$ & $4.5 \pm 1.29 \mathrm{~b}$ & $16.2 \pm 4.52 \mathrm{a}$ & $6.5 \pm 1.67 \mathrm{a}$ \\
\hline $0.5 \%$ IBA & $85 \pm 5.0 \mathrm{~b}$ & $75 \pm 5.0 \mathrm{~b}$ & $2.3 \pm 0.68 b$ & $5.8 \pm 2.54 \mathrm{a}$ & $15.3 \pm 3.93 \mathrm{a}$ & $6.1 \pm 2.14 \mathrm{ab}$ \\
\hline $0.3 \%$ IAA & $50 \pm 5.0 \mathrm{~d}$ & $40 \pm 3.5 \mathrm{de}$ & $1.5 \pm 0.34 d$ & $2.7 \pm 0.24 \mathrm{~cd}$ & $11.5 \pm 5.62 \mathrm{c}$ & $2.9 \pm 1.80 \mathrm{e}$ \\
\hline $0.4 \%$ IAA & $65 \pm 5.0 \mathrm{c}$ & $50 \pm 6.1 \mathrm{~cd}$ & $1.4 \pm 0.35 \mathrm{~d}$ & $2.6 \pm 0.40 \mathrm{~cd}$ & $14.7 \pm 1.62 \mathrm{ab}$ & $2.6 \pm 2.08 \mathrm{e}$ \\
\hline $0.5 \%$ IAA & $65 \pm 6.1 \mathrm{c}$ & $65 \pm 6.1 b c$ & $1.3 \pm 0.55 \mathrm{~d}$ & $1.5 \pm 0.47 \mathrm{e}$ & $13.6 \pm 1.54 \mathrm{abc}$ & $4.5 \pm 2.09 \mathrm{~cd}$ \\
\hline
\end{tabular}

Notes: Mean values followed by the same letter are not significantly $(p<0.05)$ different within position of shoot cuttings and auxin treatment. The $+/-$ values are the standard deviations in a particular treatment. 
The maximum ( $95 \%$ and $100 \%$ ) survival was recorded in the lower and upper position cuttings at $0.4 \%$ IBA treatment, respectively (Figure 1). Similarly, highest plantable $(100 \%)$ plants were obtained in the lower and upper portion cuttings at $0.4 \%$ IBA.

\section{Effect of leaves and auxin treatments}

Leafy branch cuttings had maximum $(90 \%)$ rooting and sprouting at $0.4 \%$ IBA treatment. In leafless cuttings, $80 \%$ rooting was recorded at the same IBA concentration. Maximum numbers of sprout/cuttings (3.6) were observed in the leafless cuttings at $0.4 \%$ IBA. Highest sprout length/cutting was recorded $(4.3 \mathrm{~cm})$ in the leafy cuttings at $0.4 \%$ IBA. The number of roots per rooted cutting was maximum $(14.6 \mathrm{~cm})$ in the leafy cuttings at $0.5 \%$ IBA. Root length to rooted cuttings was maximum $(10.2 \mathrm{~cm})$ in the leafy cuttings at $0.4 \%$ IBA (Table 2).

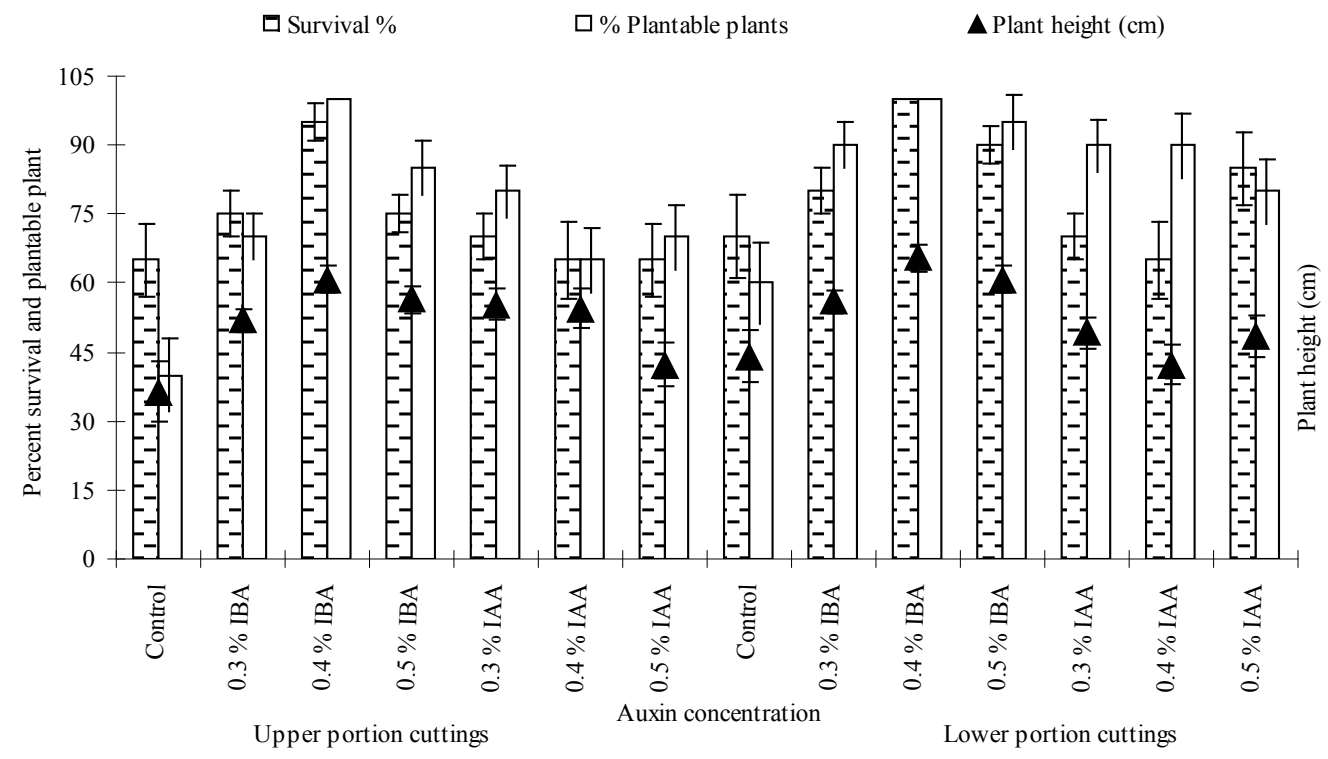

Figure 1. Effects of shoot position on percent survival, plantable plant and plant height

Table 2. Effects of leafy and leafless cuttings on rooting response of Tecoma stans

\begin{tabular}{|c|c|c|c|c|c|c|}
\hline Treatments & $\begin{array}{c}\text { Sprouting } \\
\text { \% }\end{array}$ & $\begin{array}{c}\text { Rooting } \\
\text { \% }\end{array}$ & $\begin{array}{c}\text { Number of } \\
\text { sprouts }\end{array}$ & $\begin{array}{c}\text { Sprout length } \\
(\mathbf{c m})\end{array}$ & $\begin{array}{c}\text { Number of } \\
\text { roots }\end{array}$ & $\begin{array}{c}\text { Root length } \\
(\mathbf{c m})\end{array}$ \\
\hline Leafy & & & & & \\
\hline Control & $55.0 \pm 7.9 \mathrm{c}$ & $45.0 \pm 7.9 \mathrm{c}$ & $1.2 \pm 0.22 \mathrm{c}$ & $1.4 \pm 0.80 \mathrm{~d}$ & $2.5 \pm 1.20 \mathrm{c}$ & $3.9 \pm 0.23 \mathrm{~cd}$ \\
\hline $0.3 \%$ IBA & $55.0 \pm 3.5 \mathrm{c}$ & $50.0 \pm 3.5 \mathrm{c}$ & $1.6 \pm 0.51 \mathrm{~cd}$ & $2.6 \pm 0.21 \mathrm{c}$ & $8.9 \pm 4.28 \mathrm{~b}$ & $5.2 \pm 1.29 \mathrm{c}$ \\
\hline $0.4 \%$ IBA & $90.0 \pm 3.5 \mathrm{a}$ & $90.0 \pm 3.5 \mathrm{a}$ & $2.2 \pm 0.38 \mathrm{a}$ & $4.3 \pm 0.23 \mathrm{a}$ & $13.2 \pm 2.48 \mathrm{a}$ & $10.2 \pm 2.56 \mathrm{a}$ \\
\hline $0.5 \%$ IBA & $80.0 \pm 6.1 \mathrm{ab}$ & $80.0 \pm 6.1 \mathrm{ab}$ & $2.0 \pm 0.55 \mathrm{ab}$ & $3.8 \pm 1.32 \mathrm{ab}$ & $14.6 \pm 1.80 \mathrm{a}$ & $7.3 \pm 0.21 \mathrm{~b}$ \\
\hline $0.3 \%$ IAA & $55.0 \pm 5.0 \mathrm{c}$ & $45.0 \pm 3.5 \mathrm{c}$ & $1.4 \pm 0.62 \mathrm{de}$ & $2.3 \pm 0.49 \mathrm{c}$ & $13.7 \pm 0.85 \mathrm{a}$ & $4.5 \pm 1.28 \mathrm{~cd}$ \\
\hline $0.4 \%$ IAA & $70.0 \pm 3.5 \mathrm{~b}$ & $70.0 \pm 3.5 \mathrm{~b}$ & $1.9 \pm 0.21 \mathrm{~b}$ & $3.4 \pm 0.54 \mathrm{~b}$ & $8.1 \pm 5.10 \mathrm{~b}$ & $3.1 \pm 2.12 \mathrm{~d}$ \\
\hline $0.5 \%$ IAA & $75.0 \pm 7.9 \mathrm{~b}$ & $75.0 \pm 7.9 \mathrm{~b}$ & $1.8 \pm 0.25 \mathrm{bc}$ & $2.5 \pm 0.30 \mathrm{c}$ & $8.0 \pm 3.41 \mathrm{~b}$ & $4.6 \pm 1.58 \mathrm{~cd}$ \\
\hline Leafless & & & & & \\
\hline Control & $45.0 \pm 5.0 \mathrm{~d}$ & $40.0 \pm 5.0 \mathrm{e}$ & $1.8 \pm 0.38 \mathrm{c}$ & $1.6 \pm 0.52 \mathrm{~d}$ & $1.3 \pm 0.24 \mathrm{~d}$ & $2.7 \pm 0.65 \mathrm{~d}$ \\
\hline $0.3 \%$ IBA & $65.0 \pm 6.1 \mathrm{c}$ & $50.0 \pm 5.0 \mathrm{de}$ & $2.5 \pm 0.26 \mathrm{~b}$ & $3.2 \pm 0.56 \mathrm{bc}$ & $4.3 \pm 2.08 \mathrm{~b}$ & $4.5 \pm 0.64 \mathrm{bc}$ \\
\hline $0.4 \%$ IBA & $90.0 \pm 5.0 \mathrm{a}$ & $80.0 \pm 5.0 \mathrm{a}$ & $3.6 \pm 0.56 \mathrm{a}$ & $4.1 \pm 1.29 \mathrm{~b}$ & $6.3 \pm 4.27 \mathrm{a}$ & $8.5 \pm 2.41 \mathrm{a}$ \\
\hline $0.5 \%$ IBA & $85.0 \pm 5.0 \mathrm{ab}$ & $75.0 \pm 3.5 \mathrm{a}$ & $2.8 \pm 0.68 \mathrm{~b}$ & $5.5 \pm 2.54 \mathrm{a}$ & $3.5 \pm 1.08 \mathrm{bc}$ & $5.3 \pm 2.21 \mathrm{~b}$ \\
\hline $0.3 \%$ IAA & $75.0 \pm 6.1 \mathrm{ab}$ & $55.0 \pm 3.5 \mathrm{~cd}$ & $1.5 \pm 0.34 \mathrm{c}$ & $2.3 \pm 0.24 \mathrm{~cd}$ & $2.5 \pm 1.05 \mathrm{c}$ & $3.5 \pm 1.20 \mathrm{~cd}$ \\
\hline $0.4 \%$ IAA & $80.0 \pm 3.5 \mathrm{ab}$ & $60.0 \pm 6.1 \mathrm{~cd}$ & $1.4 \pm 0.35 \mathrm{c}$ & $2.4 \pm 0.40 \mathrm{~cd}$ & $4.2 \pm 1.28 \mathrm{~b}$ & $4.2 \pm 2.05 \mathrm{bc}$ \\
\hline $0.5 \%$ IAA & $75.0 \pm 5.0 \mathrm{bc}$ & $65.0 \pm 3.5 \mathrm{bc}$ & $1.3 \pm 0.55 \mathrm{c}$ & $1.6 \pm 0.47 \mathrm{~d}$ & $3.3 \pm 0.86 \mathrm{bc}$ & $4.3 \pm 3.24 \mathrm{bc}$ \\
\hline & & & & & \\
\hline & & & & \\
\hline & & & & \\
\hline
\end{tabular}

Notes: Mean values followed by the same letter are not significantly $(p<0.05)$ different within leafy and leafless cuttings and different auxin treatments. The + /- values are the standard deviations in a particular treatment. 
Percent survival and plantable cuttings reached 100\% in the leafy cuttings at $0.4 \%$ IBA. Similarly, plantable plant height was highest $66.4 \mathrm{~cm}$ in the leafy cuttings at $0.4 \%$ IBA (Figure 2).

Effect of soft wood, hard wood cuttings and auxin treatments

Rooting and sprouting response was significantly $(p<0.05)$ influenced by hardness of cuttings. It was observed that $20 \%$ to $30 \%$ callus formation was recorded in the hard wood in control and across the various concentrations of IAA and IBA. Maximum sprouting (90\%) was recorded in soft wood cuttings with highest $(80 \%)$ rooting in the
$0.4 \%$ IBA treatment, however, statistically similar to others treatments. The number of sprouts per sprouted cutting was maximum (3.4) in the hardwood cuttings at $0.4 \%$ IBA treatment. Sprout length was greatest $(4.4 \mathrm{~cm})$ in soft wood cuttings at $0.4 \%$ IBA. The number of roots per rooted cutting was highest (14.7) in soft wood cuttings at $0.5 \%$ IBA treatment. Soft wood cuttings produce maximum $(6.7 \mathrm{~cm})$ root length in $0.4 \%$ IBA treatment (Table 3).

Soft wood cuttings had $100 \%$ survival at $0.4 \%$ IBA (Figure 3). The plantable cuttings were $100 \%$ in the soft wood at $0.4 \%$ IBA treatment. Plantable plant height was maximum $(59.3 \mathrm{~cm})$ in the soft wood cuttings at $0.4 \%$ IBA (Figure 3).

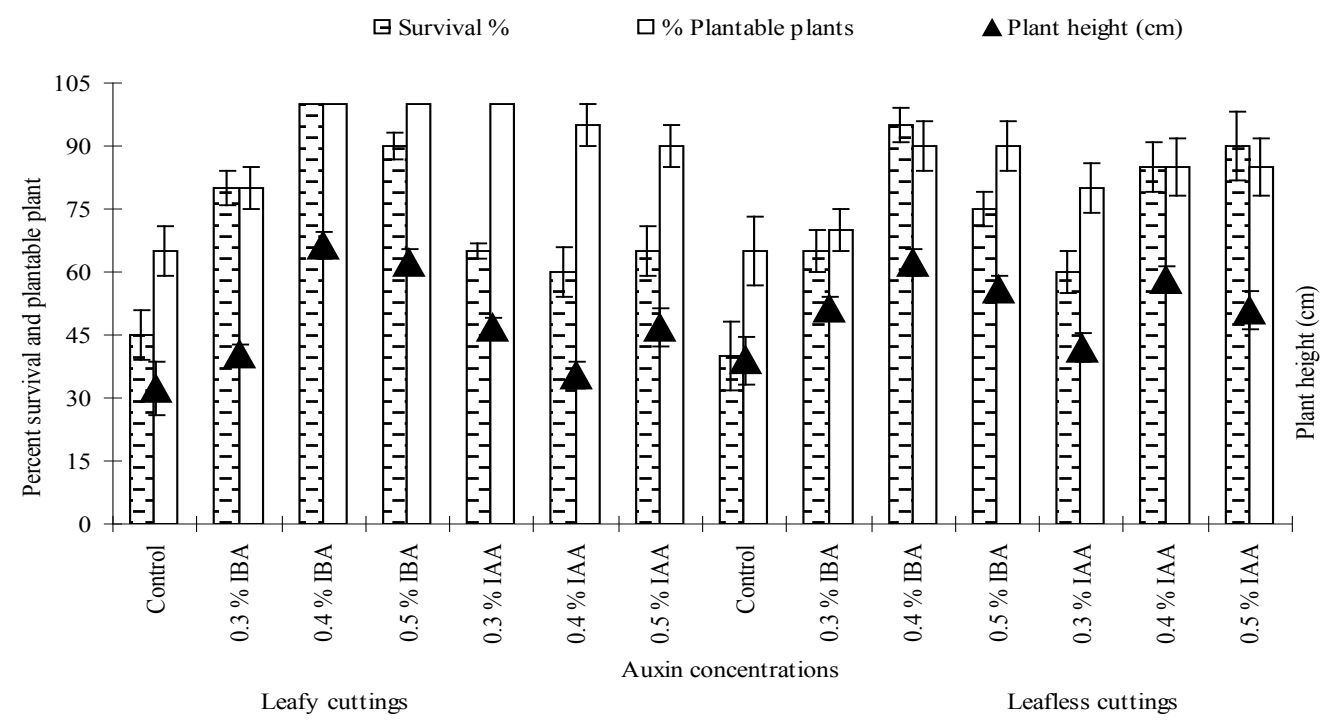

Figure 2. Effects of leaf and leafless cutting on percent survival, plantable plant and plant height.

Table 3. Effects of softwood and hardwood cuttings on rooting response of Tecoma stans

\begin{tabular}{|c|c|c|c|c|c|c|c|}
\hline Treatments & $\begin{array}{c}\text { Callus } \\
\text { \% }\end{array}$ & Sprouting \% & Rooting \% & $\begin{array}{c}\text { Number of } \\
\text { sprout }\end{array}$ & $\begin{array}{c}\text { Sprout length } \\
(\mathbf{c m})\end{array}$ & $\begin{array}{c}\text { Number of } \\
\text { root }\end{array}$ \\
\hline $\begin{array}{c}\text { Soft wood } \\
\text { Control }\end{array}$ & - & $30.0 \pm 3.5 \mathrm{~d}$ & $20.0 \pm 3.5 \mathrm{c}$ & $1.3 \pm 0.23 \mathrm{~d}$ & $1.3 \pm 0.30 \mathrm{e}$ & $3.2 \pm 2.04 \mathrm{c}$ & $3.6 \pm 0.59 \mathrm{~cd}$ \\
\hline $0.3 \%$ IBA & - & $80.0 \pm 6.1 \mathrm{ab}$ & $60.0 \pm 9.4 \mathrm{~b}$ & $1.7 \pm 0.50 \mathrm{c}$ & $2.5 \pm 0.11 \mathrm{~cd}$ & $10.9 \pm 2.96 \mathrm{~b}$ & $5.2 \pm 1.36 \mathrm{~b}$ \\
\hline $0.4 \%$ IBA & - & $90.0 \pm 7.9 \mathrm{a}$ & $80.0 \pm 7.9 \mathrm{a}$ & $2.6 \pm 0.32 \mathrm{a}$ & $4.4 \pm 0.43 \mathrm{a}$ & $14.7 \pm 3.40 \mathrm{a}$ & $6.7 \pm 2.62 \mathrm{a}$ \\
\hline $0.5 \%$ IBA & - & $80.0 \pm 5.0 \mathrm{ab}$ & $60.0 \pm 3.5 \mathrm{~b}$ & $2.2 \pm 0.76 \mathrm{~b}$ & $3.9 \pm 1.2 \mathrm{ab}$ & $12.5 \pm 3.95 \mathrm{ab}$ & $6.2 \pm 1.98 \mathrm{ab}$ \\
\hline $0.3 \%$ IAA & - & $70.0 \pm 5.0 \mathrm{bc}$ & $50.0 \pm 7.9 \mathrm{~b}$ & $1.8 \pm 0.23 \mathrm{c}$ & $2.1 \pm 0.22 \mathrm{~d}$ & $4.3 \pm 2.76 \mathrm{c}$ & $2.8 \pm 1.82 \mathrm{de}$ \\
\hline $0.4 \%$ IAA & - & $60.0 \pm 6.1 \mathrm{c}$ & $50.0 \pm 3.5 \mathrm{~b}$ & $1.9 \pm 0.43 \mathrm{c}$ & $3.0 \pm 0.34 \mathrm{bc}$ & $4.5 \pm 1.69 \mathrm{c}$ & $2.4 \pm 1.80 \mathrm{e}$ \\
\hline $0.5 \%$ IAA & - & $60.0 \pm 5.0 \mathrm{c}$ & $60.0 \pm 5.0 \mathrm{~b}$ & $1.9 \pm 0.45 \mathrm{c}$ & $2.6 \pm 0.30 \mathrm{~d}$ & $3.9 \pm 1.51 \mathrm{c}$ & $4.4 \pm 1.92 \mathrm{bc}$ \\
\hline Hardwood & & & & & & \\
\hline Control & $30.0 \pm 5.0 \mathrm{a}$ & $40.0 \pm 3.5 \mathrm{~d}$ & $0.00 \pm 0.0 \mathrm{e}$ & $1.6 \pm 0.43 \mathrm{c}$ & $1.8 \pm 0.52 \mathrm{~d}$ & $0.00 \mathrm{c}$ & $0.00 \mathrm{~d}$ \\
\hline $0.3 \%$ IBA & $20.0 \pm 3.5 \mathrm{~b}$ & $40.0 \pm 6.1 \mathrm{~d}$ & $20.0 \pm 6.1 \mathrm{c}$ & $2.8 \pm 0.62 \mathrm{~b}$ & $3.7 \pm 0.68 \mathrm{bc}$ & $1.2 \pm 0.30 \mathrm{~b}$ & $3.5 \pm 1.25 \mathrm{a}$ \\
\hline $0.4 \%$ IBA & $30.0 \pm 5.0 \mathrm{a}$ & $65.0 \pm 3.5 \mathrm{~b}$ & $35.0 \pm 3.5 \mathrm{ab}$ & $3.4 \pm 0.64 \mathrm{a}$ & $4.1 \pm .87 \mathrm{~b}$ & $2.0 \pm 0.64 \mathrm{a}$ & $3.3 \pm 2.45 \mathrm{ab}$ \\
\hline $0.5 \%$ IBA & $30.0 \pm 5.0 \mathrm{a}$ & $75.0 \pm 5.0 \mathrm{a}$ & $45.0 \pm 7.9 \mathrm{a}$ & $2.9 \pm 0.34 \mathrm{ab}$ & $4.3 \pm 1.20 \mathrm{a}$ & $1.5 \pm 0.62 \mathrm{~b}$ & $3.6 \pm 0.56 \mathrm{a}$ \\
\hline $0.3 \%$ IAA & $20.0 \pm 3.5 \mathrm{~b}$ & $50.0 \pm 3.5 \mathrm{c}$ & $30.0 \pm 3.5 \mathrm{bc}$ & $1.6 \pm 0.36 \mathrm{c}$ & $2.1 \pm 0.57 \mathrm{~cd}$ & $1.1 \pm .043 \mathrm{c}$ & $1.7 \pm 0.45 \mathrm{c}$ \\
\hline $0.4 \%$ IAA & $30.0 \pm 3.5 \mathrm{a}$ & $60.0 \pm 6.1 \mathrm{~b}$ & $20.0 \pm 3.5 \mathrm{c}$ & $1.5 \pm 0.31 \mathrm{c}$ & $2.2 \pm 0.27 \mathrm{~cd}$ & $1.3 \pm 0.32 \mathrm{~b}$ & $2.1 \pm 2.01 \mathrm{c}$ \\
\hline $0.5 \%$ IAA & $30.0 \pm 3.5 \mathrm{a}$ & $60.0 \pm 5.0 \mathrm{~b}$ & $30.0 \pm 5.0 \mathrm{bc}$ & $1.5 \pm 0.32 \mathrm{c}$ & $1.4 \pm 0.43 \mathrm{~d}$ & $1.7 \pm 0.58 \mathrm{ab}$ & $2.5 \pm 0.89 \mathrm{bc}$ \\
\hline & & & & & & \\
\hline & & & & & \\
\hline & & & & & \\
\hline
\end{tabular}

Notes: Mean values followed by the same letter are not significantly $(p<0.05)$ different within soft wood and hardwood cuttings and different auxin treatments. The $+/$ - values are the standard deviations in a particular treatment. 


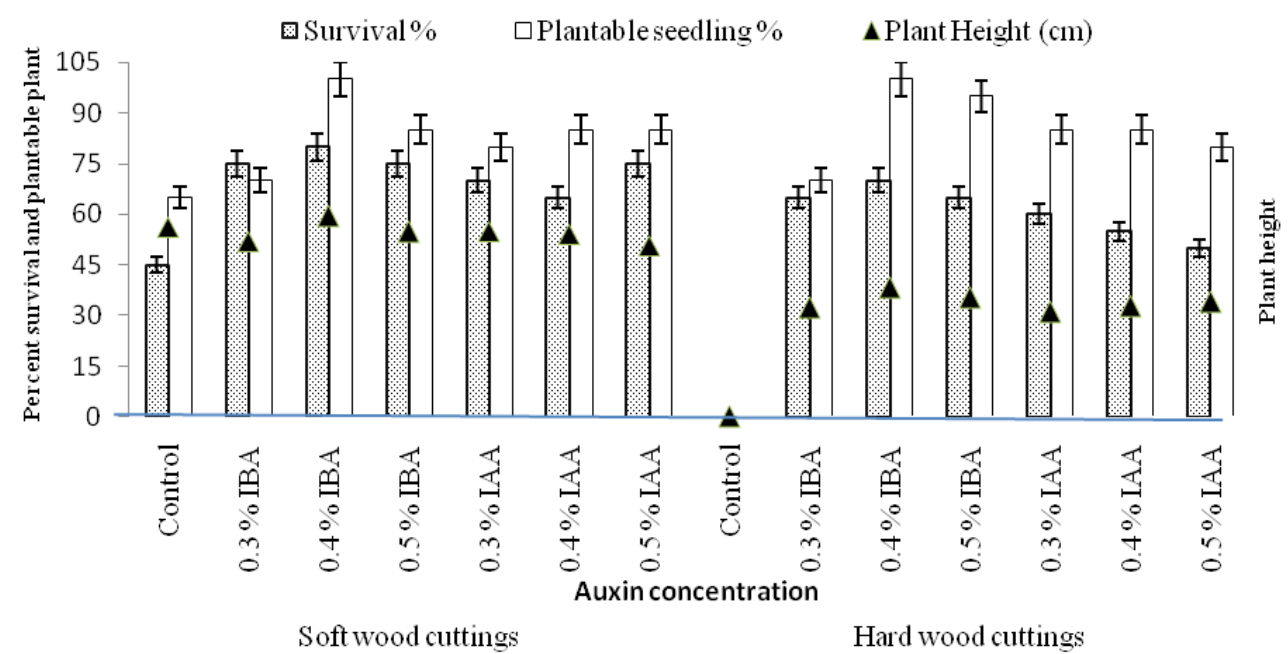

Figure 3. Effects of soft wood and hard wood cuttings on percent survival and plantable plant.

\section{Discussion}

The cuttings of T. stans taken from upper and basal portions of shoot showed significant $(p<0.05)$ variation in the rooting responses. Twenty and thirty percent rooting was recorded in the control set in the upper and basal portion cuttings, respectively indicating that the lower portion cuttings produce more roots compared to the upper portion cuttings in this experiments. Rooting capacity was highest in petunia cuttings due to the maximum auxin concentration in the stem base of cutting (Lischewski et al., 2015). Polar auxin transport and cutting off from the basipetal auxin drain are considered as initial principles generating early accumulation of auxin in the rooting zone (Druege et al., 2016) and the rise of free auxin in the basal stem probably contributes to the early events of adventitious root formation. In T. stans, carbohydrate content might be higher in the basal portion cuttings compared to upper portion cuttings and this was probably responsible for the greater rooting, survival and the production of welldeveloped plants.

Maximum rooting and sprouting in T. stans was recorded in leafy cuttings as compared to the non leafy cuttings. Control set of leafy cuttings had higher rooting compared to leafless cuttings. Similar results were also recorded for Sterculia foetida (Azad et al., 2018) and Cannabis sativa (Caplan et al., 2018). Cuttings with leaves were photosynthesizing during propagation. The fact that leafless cuttings had basal rooting capacity implies that photosynthesis was of importance for root development.

Cell division and cell enlargement during adventitious root formation require high input of energy and carbon skeletons. Auxin and ethylene interactions positively regulate adventitious root formation in Arabidopsis thaliana (Veloccia et al., 2016). Leaves and buds are also a source of auxin which may transport sugars to the regions of root primordial development (Haissig, 1982). This endogenous source of auxin may also be important in this species, although this has not been specifically investigated. The effect of physiological age on plant material at the time of harvesting for propagation has been documented as an important factor in Tecoma stans (Cervery, 2006). Terminal stems generally produce a more efficient crop, by effective rooting in the quickest time. Older stem tissue is slower to root than younger tissue (Dole and Wilkins, 1999). In the present study soft wood cuttings proclaimed greater sprouting and rooting and other related parameters as compared to the hard wood cuttings. However, rooting ability of cuttings was significantly varies in leafy cuttings in Santalum austrocaledonicum (Tate and Page, 2018).

Soft wood cuttings produced maximum root in $0.4 \%$ IBA while hard wood cuttings formed more root in $0.5 \%$ IBA. The hardwood cuttings failed to root in control set. In the present study soft wood cuttings gave greater sprouting, rooting and other related parameters as compared to the mature wood cuttings. Similar finding was reported in Diploknema butyracea (Zargar and Kumar, 2018) and Taxus baccata (Das and Jha, 2018). Juvenility of cutting in Dryobalanops aromatic resulted high survival percentage (Susilowati et al., 2018). The rooting ability of juvenile cuttings may be related to low levels of rooting inhibitors and high levels of photosynthetic and when the plant grows older, the capacity of inhibitor levels increases (Kontoh, 2016).

The treatments of IBA enhanced rooting when compared to IAA. Treatments with IBA also improved the remaining cutting variables. Previous studies have also shown that IBA increased the number of roots in Araucaria heterophylla (Tilahun et al., 2019). IBA-induced increase the number and length of roots. The rooting percentage showed an increasing trend with increasing concentrations to $0.4 \%$ IBA above which the rooting trend was declined. Applications of auxin enhanced rooting and root quality in many tree species (Hartmann et al., 2018). IBA at 4000 ppm induced maximum rooting and produce high quality planting stock in Swietenia macrophylla (Azad and Matin, 2015). While for Duranta erecta 5000 ppm was the best for rooting and furthers than that the inhibitory effects on the rooting was apparent (Shiri et al., 2019). IBA treated cuttings produced higher rooting percentage, number of 
roots and root length than untreated cuttings revealing a strong IBA influence on rooting ability of stem cuttings in Swietenia macrophylla (Azad and Matin, 2015). Root and shoots initiation were significantly promoting by the hormonal concentrations (Kala et al., 2017; Singh, 2017).

\section{Conclusions}

The results of the study conclude that (i) 0.4 to $0.5 \%$ IBA concentrations is effective for best rooting in T. stans, (ii) softwood cuttings taken from lower position cuttings with leaves had prominent rooting response in $T$. stans even under controlled conditions (without auxin treatment). Therefore, lower portion soft wood cuttings with leaves is recommended best cutting for rooting in T. stans in a mist chamber. It is ample clear from the results that $T$. stans is a relatively easy species to root. The results of the present study will be helpful to commercial nursery growers to produce quality planting material of $T$. stans.

\section{Author Contribution}

BS: conduction and evaluation of the experiment and writing of the manuscript; JMSR: conduction and evaluation of the experiment and writing of the manuscript; YSG: helping in manuscript writing; VPK: modification, improvement and corrections in manuscript; MKR: statistical analysis and PK: helps in setting up of experiments.

\section{References}

ABO EL-ENIEN, H.E.; OMAR, M.A. Effect of some growth substances on rooting and endogenous hormones of Casimiroa edulis L. cuttings. Zagazig Journal of Agriculture Research, v.45, n.3, p.891-904, 2018.

AZAD, M.D. SALIM.; ALAM, M.; MOLLICK, A.; MATIN, M.D. Responses of IBA on rooting, biomass production and survival of branch cuttings of Santalum album L., a wild threatened tropical medicinal tree species. Journal of Science Technology and Environment Informatics, v.3, n.2, p.195-206, 2016. https://doi. org/10.18801/jstei.030216.22.

AZAD, M.D. SALIM.; ALAM, M.D.; MOLLICK, A.; KHAN, M.D. NABIUL. Rooting of cuttings of the wild Indian almond tree (Sterculia foetida) enhanced by the application of indole-3-butyric acid (IBA) under leafy and non-leafy conditions. Rhizosphere, v.5, p.8-15, 2018. https://doi.org/10.1016/j.rhisph.2017.11.001.

AZAD, M.D. SALIM.; MATIN, M.D. Effect of Indole3-Butyric Acid on clonal propagation of Swietenia macrophylla through Branch Cutting. Journal of Botany, v.1, n.7, 2015. https://doi.org/10.1155/2015/249308.
BIONDI, D.; BREDOW, E.A.; EDGARD, A.; LEAL. L. Cuttings diameter influence in the rooting of Tecoma stans (L.) Juss. ex. Kunth., Semina - Ciencias Agrarias, v.29, n.2, p.277-282, 2008.

CAPLAN, D.; STEMEROFF, J.; DIXON, M.; ZHENG, Y. Vegetative propagation of cannabis by stem cuttings: effects of leaf number, cutting position, rooting hormone, and leaf tip removal. Canadian Journal of Plant Sciences, v. 98, n.5, p.1126-1132, 2018. https://doi.org/10.1139/cjps-20180038 .

CERVENY, C.B.; CIBSION, J.; BARRETT, J.E. Influence of stem cutting location on propagation of Tecoma stans and Murraya paniculata. HortScience, v. 41, n.3, p.500501, 2006.

DAS, S.; JHA, L.K. Effect of different rooting media on root proliferation of Taxus baccata L. stem cuttings. Current Agriculture Research Journal, v.6., n.1, p.95104, 2018. https://doi.org/10.12944/CARJ.6.1.12.

DOLE, J.M.; WILKINS, W.B. Lilium, Asiatic, Oriental. In: Floriculture Principles and Species. Upper Saddle River: Prentice Hall. Inc., 1999. 416p.

DRUEGE, U.; FRANKEN, P.; HAJIREZAEI, M.R. Plant hormone homeostasis, signaling, and function during adventitious root formation in cuttings. Frontiers in Plant Sciences, v.7, n.381, 2016. https://doi.org/10.3389/ fpls.2016.00381.

HAISSIG, B.E. Carbohydate and amino acid concentrations during adventitious root primordium development in Pinus banksiana. Forest Science, v.28, n.4, p.813-821, 1982.

HARTMANN, H.T.; KESTERS, D.E.; DAVIES, F.E.; GENEVE, R. Plant Propagation: principles and practices. 9ed. New Delhi: Prentice Hall of India Pvt. Ltd., 2018. 880p

IBIRONKE, O.A. Response of selected ornamentals to rooting hormone in different propagating media. Journal of Botany Research, v.1, n.1, p.22-28, 2017. https://doi. org/10.36959/771/55.

KALA, S.; REEJA, S.; KUMARAN, K. First report on success of stem cuttings on Simarouba glauca, Dc-An easy method for mass multiplication of superior mother trees. International Journal of Current Microbiology and Applied Sciences, v.4, n.6, p.2646-2653, 2017. https://doi. org/10.20546/ijcmas.2017.604.308.

KONTOH, I.H. Effect of growth regulators and soil media on the propagation of Voacanga africana stem cuttings. Agroforestry Systems, v.90, n.3, p.479-488, 2016. https:// doi.org/10.1007/s10457-015-9870-2. 
LISCHWESKI，S.; MUCHOW，A.; GUTHORL, D.; HAUSE, B. Jasmonates act positively in adventitious root formation in petunia cuttings. BMC Plant Biology, v.15, n.229, 2015. https://doi.org/10.1186/s12870-015-0615-1.

PIZARRO, A.; DIAZ-SALA, C. Cellular dynamics during maturation-related decline of adventitious root formation in forest tree species. Physiologia Plantarum, v.165, n.1, p.73-80, 2019. https://doi.org/10.1111/ppl.12768.

RENO, L. R.; MOSCHETA, I.S.; BRACCINI, A.L. Morphology and anatomy of the fruit and seed of yellow trumpet flower (Tecoma stans (L) Kunth- Bignoniaceae). Revista Brasileira de Sementes, v.29, n.3, p.18-30, 2007. https://doi.org/10.1590/S0101-31222007000300003.

ROGER, D.P. Exploratory Data Analysis with R. Morrisville: Publisher Lulu.com, 2016. 288p.

SHIRI, M.; MUDYIWA, R.M.; TAKAWIRA, M.; MUSARA, C.; GAMA, T. Effects of rooting media and indole-3-butyric acid (IBA) concentration on rooting and shoot development of Duranta erecta tip cuttings. African Journal of Plant Science, v.13, n.10, p.279- 285, 2019. https://doi.org/10.5897/AJPS2019.1851.

SINGH, B.; RAWAT, J.M.S. Effects of cuttings type and hormonal concentration on vegetative propagation of Zanthoxylum armatum DC., Prodr. in Garhwal Himalaya, India. Journal of Forestry Research, v.28, n.2, p. 419423, 2017.

SINGH, K.S. Multiplication of Phalsa (Grewia asetica L.) Cv. Dwarf type through hardwood stem cutting under Srinagar Garhwal Himalayas. International Journal of Current Microbiology and Applied Sciences, v.6, n.2, p.1173-1178, 2017. http://dx.doi.org/10.20546/ijcmas.2017.602.132.
STEFFENS, B.; RASMUSSEN A. The physiology of adventitious roots. Plant Physiology, v.170, n.2, p.603617, 2016. https://doi.org/10.1104/pp.15.01360

SUSILOWATI, A.; KHOLIBRINA, R.C.; RACHMAT, H.H..; ASWANDI, D.E.; RAENI, I.M. Macropropagation - An important tool for conservation of North Sumatran endangered tree species, Dryobalanops aromatic. Biodiversitas, v.19, n.5, p.1672-1675, 2018. https://doi. org/10.13057/biodiv/d190511.

TATE, H.T.; PAGE, T. Cutting propagation of Santalum austrocaledonicum: the effect of genotype, cutting source, cutting size, propagation medium, IBA Irradiance. New Forest, v.49, n.4, p.551-570, 2018. https://doi.org/10.1007/ s11056-018-9638-4.

TILAHUN, A.; MANAHLIE, B.; ABEBE, G.; NEGASH, G. Effect of cutting position and indole butyric acid (auxin) concentration on rooting response of Araucaria heterophylla. African Journal of Biotechnology, v.18, n.4, p.86-91, 2019. https://doi.org/10.5897/AJB2018.16450.

VELOCCIA, A.; FATTORINI, L.; DELLA ROVERE, F., SOFO, A.; D'ANGELI, S.; BETTI, C.; FALASCA, G.; ALTAMURA, M.M. Ethylene and auxin interaction in the control of adventitious rooting in Arabidopsis thaliana. Journal of Experimental Botany, v.67, n.22, p.64456458, 2016. https://doi.org/10.1093/jxb/erw415.

VERMA, S. Phytochemical and pharmacological review study on Tecoma stans Linn. Journal of Medicinal Plants Studies, v.4, n.5, p.162-164, 2016.

ZARGAR, A.A.; KUMAR, D. Effect of maturity stage of donor plant on propagation of Diploknema butyracea through Branch Cuttings. World Journal of Agriculture Research, v.6, n.1, p.15-19, 2018. https://doi.org/10.12691/ wjar-6-1-4. 